\title{
PENGEMBANGAN PERANGKAT PEMBELAJARAN MENGGUNAKAN ALAT PERAGA FLUIDA DINAMIS UNTUK MENINGKATKAN HASIL BELAJAR
}

\author{
Alviando Stevani Mumu, Ferdy Dungus, Aswin Hermanus Mondolang \\ Fakultas Matematika dan Ilmu Pengetahuan Alam, Universitas Negeri Manado \\ email: alviandostevan@gmail.com
}

\begin{abstract}
ABSTRAK
Pembelajaran yang efisien dan efektif berawal dari perencanaan yang efektif. Penelitian ini bertujuan untuk membuat produk pengembangan perangkat pembelajaran fisika berbasis masalah menggunakan alat peraga fluida dinamis untuk meningkatkan hasil belajar siswa SMA Negeri 1 Tompaso. Penelitian ini menggunakan metode penelitian dan pengembangan "research and development" (R \& D) dengan mengikuti tahap-tahap penelitian pengembangan Borg dan Gall. Setelah produk pengembangan perangkat dibuat dan di uji kelayakan oleh ahli materi, ahli media dan ahli perangkat pembelajaran yang menyatakan bahwa perangkat pembelajaran Fisika berbasis masalah menggunakan alat peraga Fluida Dinamis sudah valid dan layak untuk digunakan dalam pembelajaran. Kemudian sebelum dilakukan kegiatan pembelajaran, dilakukan pre-test untuk mengetahui kemampuan awal siswa dan pada akhir pertemuan dilakukan post-test untuk melihat apakah ada peningkatan rata-rata nilai hasil belajar siswa setelah mengikuti pembelajaran menggunakan perangkat pembelajaran yang dikembangkan. Berdasarkan hasil tes dapat dilihat adanya peningkatan nilai rata-rata hasil belajar siswa yaitu sebesar 13,30. Berdasarkan kriteria pengujian statistik, maka dapat disimpulkan bahwa terdapat perubahan signifikan dalam hasil belajar siswa kelas XI MIPA 2 SMA Negeri 1 Tompaso setelah mengikuti pembelajaran menggunakan perangkat pembelajaran Fisika berbasis masalah menggunakan alat peraga Fluida Dinamis yang dikembangkan oleh peneliti.
\end{abstract}

Kata kunci : Pengembangan, Perangkat Pembelajaran, Problem Based Learning (PBL), Fluida Dinamis

\begin{abstract}
Efficient and effective learning begins with effective planning. This study aims to create a problem-based physics learning device development product using dynamic fluid visual aids to improve student learning outcomes at SMA Negeri 1 Tompaso. This research uses the research and development $(R \& D)$ method by following the stages of Borg and Gall development research. After the device development product was made and tested for feasibility by material experts, media experts and learning device experts who stated that problem-based physics learning tools using Dynamic Fluids were valid and suitable for use in learning. Then before the learning activities are carried out, a pre-test is carried out to determine the students' initial abilities and at the end of the meeting a post-test is carried out to see if there is an increase in the average value of student learning outcomes after participating in learning using the developed learning tools. Based on the test results, it can be seen that there is an increase in the average value of student learning outcomes, which is 13,30. Based on the statistics testing criteria, which means that it can be concluded that there is a significant change in student learning outcomes of class XI MIPA 2 SMA Negeri 1 Tompaso after participating in learning using problem-based Physics learning tools using the Dynamic Fluids teaching aid developed by the researcher.
\end{abstract}

Keywords : Development, Learning Tools, Problem Based Learning (PBL), Dynamic Fluid 


\section{PENDAHULUAN}

Pembelajaran pada dasarnya adalah upaya untuk membantu peserta didik melakukan kegiatan belajar. Tujuan pembelajaran adalah terwujudnya efisiensi dan efektivitas kegiatan belajar yang dilakukan peserta didik. Adapun pendidikan yang bertujuan untuk menyediakan lingkungan yang memungkinkan peserta didik untuk mengembangkan bakat dan kemampuannya secara optimal. Dengan adanya lingkungan yang memungkinkan, peserta didik dapat mewujudkan dirinya dan berfungsi sepenuhnya sesuai dengan kebutuhan pribadinya. Keberhasilan siswa dalam mencapai prestasi yang baik pada pembelajaran Fisika merupakan salah satu indikator keberhasilan. Pada dasarnya, Fisika adalah ilmu dasar seperti halnya kimia, biologi, astronomi dan geologi. Ilmu-ilmu dasar diperlukan dalam berbagai cabang ilmu pengetahuan terapan dan teknik. Teori fisika tidak hanya cukup dibaca, sebab teori Fisika tidak sekedar hafalan saja akan tetapi harus dibaca dan dipahami dan dipraktikkan sehingga peserta didik mampu menjelaskan permasalahan yang ada.

Pembelajaran di sekolah-sekolah selama ini cenderung masih banyak yang didominasi oleh guru, siswa hanya menerima pengetahuan yang diberikan guru tanpa mengolah potensi yang ada. Seringkali guru lebih mendahulukan ketercapaian target kurikulum dan hasil akhir bahkan lebih terfokus pada hasil belajar berupa pengetahuan semata. Akibatnya makna proses pembelajaran kurang dirasakan bagi bekal dalam memecahkan permasalahan kehidupannya dan ini berarti bahwa pada umumnya, pembelajaran di sekolah belum mengajak siswa untuk menerapkan, mengelolah, setiap unsur-unsur konsep yang dipelajari untuk membuat sintesis, siswa belum diajak untuk melakukan penilaian terhadap dirinya sendiri, orang lain dan kelompok dalam kegiatan pembelajaran, belum mengajak siswa berpikir kritis terhadap konsep-konsep dan prinsip-prinsip yang telah dipelajarinya. Sementara itu, aspek keterampilan dan sikap juga banyak terabaikan.

Basar (2004:2) mengatakan bahwa pengajar Fisika di sekolah lebih sering membahas teori dari buku pegangan yang digunakan, kemudian memberikan rumusrumusnya lalu memberikan contoh soal.
Akibatnya ilmu Fisika tereduksi menjadi bacaan dan siswa hanya dapat membayangkan. Jika fenomena fisis yang sedang dibahas telah pernah dilami oleh siswa mungkin siswa akan dapat merekonstruksinya kembali menjadi pemahaman yang lebih baik.

Seorang guru harus mampu memberikan motivasi kepada siswa, untuk mengembangkan dan memanfaatkan potensi, bakat dan kemampuan yang dimilikinya. Guru bertanggung jawab untuk menciptakan situasi yang mendorong terjadinya prakarsa, motivasi belajar pada peserta didik. Sehingga guru harus bisa menerapkan model pembelajaran yang inovatif dan memperhatikan strategi belajar mengajar ini meliputi pemilihan pendekatan, metode serta media pembelajaran. Untuk meningkatkan keberhasilan dalam pembelajaran maka diperlukan suatu strategi dan rancangan pembelajaran yang tepat dan bermakna. Penerapan Pembelajaran berbasis masalah yang diintegrasikan dengan pendidikan lingkungan yang dapat digunakan dengan baik jika dilakukan proses perencanaan pembelajaran terlebih dahulu. Pada tahap perencanaan ini disusun perangkat pembelajaran meliputi rencana pelaksanaan pembelajaran, media, sumber belajar, perangkat penilaian pembelajaran, dan skenario pembelajaran karena pembelajaran ini bersifat kontruktivisme. Barrett (2011), Problem Based Learning (PBL) merupakan pembelajaran yang dihasilkan dari suatu proses pemecahan masalah yang disajikan diawal proses pembelajaran. Siswa belajar dari masalah yang nyata dalam kehidupan sehari-hari, mengorganisasi, merencana serta memutuskan apa yang dipelajari dalam kelompok kecil. Masalah ini digunakan untuk mengaitkan rasa keingintahuan serta kemampuan analisis siswa dan inisiatif atas materi pelajaran. Problem Based Learning (PBL) mempersiapkan siswa untuk berpikir kritis dan analitis, dan untuk mencari serta menggunakan sumber pembelajaran yang sesuai.

Problem Based Learning (PBL) merupakan pendekatan yang efektif untuk memproses informasi yang sudah jadi dalam benaknya dan menyusun pengetahuan mereka sendiri tentang dunia sosial, lingkungan dan sekitarnya. Dengan Problem Based Learning (PBL) siswa dilatih menyusun sendiri 
pengetahuannya,

mengembangkan keterampilan memecahkan masalah. Selain itu, dengan pemberian masalah autentik, siswa dapat membentuk makna dari bahan pelajaran melalui proses belajar dan menyimpannya dalam ingatan sehingga sewaktu-waktu dapat digunakan lagi.

Kenyataan di atas juga terjadi dalam pembelajaran Fisika di SMA N 1 Tompaso. Pembelajaran di sekolah yang hanya didominasi oleh guru tanpa mengolah potensi siswa. Maka berdasarkan uraian tersebut, akan dikembangkan suatu perangkat pembelajaran fisika berbasis masalah menggunakan alat peraga fluida dinamis. Perangkat pembelajaran yang dikembangkan disesuaikan dengan karakteristik kurikulum 2013. Dalam mengembangkan suatu perangkat pembelajaran, guru harus menguasai strategi/metode pembelajaran yang terus berkembang dari masa kemasa dan disesuaikan dengan perkembangan kurikulum yang ada. Perangkat pembelajaran dapat menyediakan kegiatan pembelajaran lebih terencana dengan baik, mandiri, tuntas, dan dengan hasil output yang jelas. Perangkat pembelajaran dapat memfasilitasi siwa lebih tertarik dalam belajar, dan dapat meningkatkan hasil belajar siswa.

\section{METODE PENELITIAN}

Penelitian ini menggunakan metode penelitian dan pengembangan "research and development" ( $\mathrm{R} \& \mathrm{D})$. Dengan mengikuti tahap-tahap penelitian pengembangan menurut Ditnaga Dirjen Dikti (2008) yang diadaptasi dari Borg and Gall (Gall dan Borg, 2003) dengan langkah-langkah pada Gambar 1 berikut:

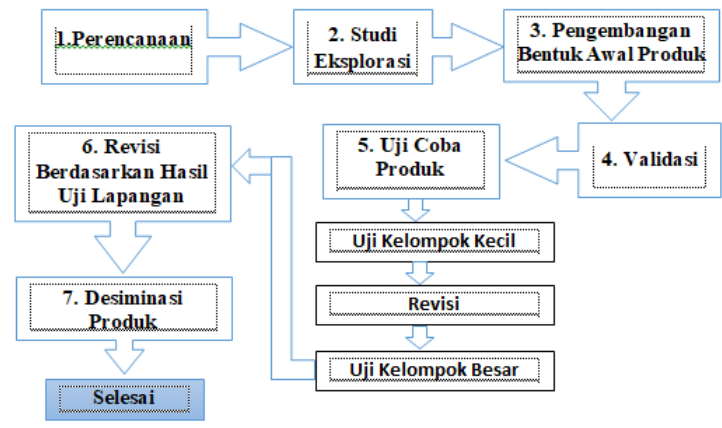

Gambar 1. Langkah-langkah penelitian pengembangan Borg \& Gall

Penelitian akan dilaksanakan di SMA NEGERI 1 TOMPASO. Adapun waktu pelaksanaan penelitian ini pada semester ganjil bulan Oktober pada tahun ajaran 2017/2018.

Objek dalam penelitian ini adalah Perangkat Pembelajaran Fisika Berbasis Masalah Menggunakan Alat Peraga Fluida Dinamis, silabus, rancangan proses pembelajaran, modul pembelajaran, lembar kerja siswa, dan alat eksperimen sederhana. Subjek dalam penelitian pengembangan ini adalah seluruh siswa SMA N 1 Tompaso tahun ajaran 2017/2018 dengan populasi terjangkaunya menggunakan dua kelas yaitu kelas XI MIPA 2 (Kelas Eksperimen) dan kelas XI MIPA 1 (Kelas Kontrol) SMA N 1 Tompaso. Kelas Eksperimen dengan jumlah 25 siswa dan kelas kontrol dengan jumlah 25 siswa.

Adapun teknik pengumpulan data yang digunakan pada penelitian ini adalah sebagai berikut: (a) Data respon siswa terhadap produk, penilaian antar teman evaluasi para pakar, diperoleh dengan menjalankan angket, format evaluasi dan tes sesuai dengan tahapan penelitian pengembangan. (b) Data keterampilan proses sains, psikomotor, prilaku berkarakter, dan keterampilan sosial diperoleh dengan melakukan penilaian secara observasi berdasarkan instrument penilaian yang telah dibuat. (c) Data hasil belajar siswa diperoleh pada tahapan ini, yaitu tahapan uji coba lapangan sesuai dengan prosedur disain sama subject.

\section{Teknik Analisis Data}

Setelah memperoleh data, selanjutnya adalah menganalisis data tersebut. Menurut Arikunto (2015), interpretasi skor dan perhitungan analisis desktiptif presentase secara kontinu dapat dibuat kategori pada gambar 2.

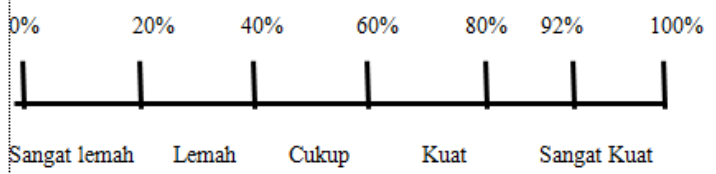

Gambar 2. Evaluasi secara kontinu

Selanjutnya, Analisis Uji dilakukan untuk menguji hipotesis penelitian dengan menggunakan analisis statistic Paired Sampel $T$ Test dimana untuk menguji perbedaan ratarata antara dua sampel yang berpasangan yang diambil dari populasi yang sama dengan menggunakan pengolahan data software SPSS 22. Data diambil dari tes awal yakni sebelum dilakukan perlakuan dan tes akhir sesudah perlakuan diberikan dalam pembelajaran 
dengan menggunakan perangkat pembelajaran yang dikembangkan.

Kriteria pengujian hipotesis pada hasil belajar yaitu

$$
\begin{aligned}
& \mathrm{H}_{0}=\mu_{1} \geq \mu_{2} \\
& \mathrm{H}_{1}=\mu_{1}<\mu_{2}
\end{aligned}
$$

\section{HASIL DAN PEMBAHASAN Hasil}

Penelitian ini dilaksanakan dengan mengikuti kegiatan mata pembelajaran fisika yang sesuai dengan jadwal penelitian pada Bab III. Berdasarkan rancangan pengembangan, penelitian ini menggunakan metode kuasi eksperimen.

Dalam penelitian ini sampel yang digunakan sebagai kelas eksperimen adalah siswa semester Ganjil kelas XI MIPA 2 dengan jumlah 25 siswa dan sampel yang digunakan sebagai kelas control adalah siswa semester ganjil kelas XI MIPA 1 dengan jumlah 25 siswa di SMA N 1 Tompaso tahun pelajaran 2017/2018. Penelitian ini dilaksanakan dengan model pembelajaran berbasis masalah dengan materi Fisika mengacu pada kurikulum yang berlaku yaitu kurikulum 2013 sesuai dengan peraturan pemerintah No. 53 tahun 2015.

Penelitian ini dilaksanakan dengan tujuan agar siswa mampu mencapai kompetensi yang diharapkan melalui Perangkat Pembelajaran Fisika Berbasis Masalah Menggunakan Alat Peraga Fluida Dinamis. Sebelum melaksanakan penelitian peneliti merancang serta membuat Perangkat Pembelajaran Fisika Berbasis Masalah Menggunakan Alat Peraga Fluida Dinamis.

Berdasarkan perhitungan yang ada pada tabel validasi para ahli, pengamatan yang dilakukan ahli perangkat pembelajaran secara keseluruhan mencapai $98,9 \%$, pengamatan yang dilakukan ahli media pembelajaran mencapai $96,7 \%$ dan pengamatan yang dilakukan ahli materi mencapai $86,7 \%$. Jika dilihat pada tabel kriteria kelayakan, maka skor dari validasi parah ahli ini termasuk dalam kriteria sangat valid atau layak untuk digunakan.

Tahap awal pengujian untuk bahan ajar Fisika berbasis masalah ini adalah uji kelompok kecil. Jumlah siswa yang diambil dalam uji kelompok kecil adalah 6 siswa untuk menguji bahan ajar fisika berbasis masalah. Hasil dari uji coba awal pengujian kelompok kecil ini ditampilkan pada tabel tanggapan siswa untuk uji kelompok kecil.

Berdasarkan data yang diambil lewat tabel tanggapan siswa pada kelompok kecil terhadap Pengembangan Perangkat Pembelajaran Fisika Berbasis Masalah Berbasis Masalah Menggunakan Alat Peraga Fluida Dinamis, terlihat bahwa hasil perhitungan rata-rata dan presentase respon siswa yang memberi pilihan kategori "sangat setuju" (SS) adalah 76,7\%, sedangkan siswa yang memberi respon pada kategori "setuju" (S) yaitu $21,7 \%$, dengan demikian dari hasil persentase tersebut menyatakan bahwa pengembangan bahan ajar ini memiliki nilai yang baik untuk siswa terhadap indicator tanggapan yang dikemukakan sebesar 98,4\%. Siswa yang memberi respon "kurang setuju" (KS) adalah 1,6\% dan tidak ada siswa yang memilih kategori "tidak setuju" (TS) dan "sangat tidak setuju" (STS).

Data respon siswa dalam kelompok kecil mengenai PengembanganPerangkat Pembelajaran Fisika Berbasis Masalah Menggunakan Alat Peraga Fluida Dinamis tersebut kemudian dianalisis dengan menghitung presentase skala likert. Dan berdasarkan analisis tersebut diperoleh presentase rata-rata pengukuran likert sebesar 95,3\% maka kriteria skor untuk perangkat pembelajaran yang dikembangkan sangat kuat.

Data yang ada dalam tahapan ini adalah uji coba Perangkat Pembelajaran Fisika Berbasis Masalah Menggunakan Alat Peraga Fluida Dinamis yang telah diujikan kepada kelompok kecil pada tahap sebelumnya. Adapun jumlah siswa yang mengikuti pembelajaran menggunakan perangkat pembelajaran ini berjumlah 25 orang. Hasil dari uji coba lapangan untuk Perangkat Pembelajaran Fisika Menggunakan Alat Peraga Fluida Dinamis untuk meningkatkan hasil belajar siswa SMA N 1 Tompaso.

Berdasarkan data yang diambil lewat tabel tanggapan siswa pada uji kelompok besar terhadap pengembangan Perangkat Pembelajaran Fisika Berbasis Masalah Menggunakan Alat Peraga Fluida Dinamis terlihat hasil perhitungan total frekuensi ratarata $55,2 \%$ siswa memberi pilihan kategori "sangat setuju" (SS), 37,6\% siswa memberi pilihan kategori "setuju" (S). maka indikator tanggapan yang dikemukakan sebesar 92,6\%, dengan demikian hasil tersebut menyatakan 
bahwa perangkat pembelajaran ini memiliki nilai yang baik bagi siswa. Kemudian terdapat 6,4\% siswa memberi pilihan kategori "kurang setuju" (KS), 0,8\% siswa memilih kategori "tidak setuju" (TS) dan tidak ada siswa yang memilih kategori "sangat tidak setuju" (STS).

Data tanggapan siswa terhadap perangkat pembelajaran tersebut kemudian dianalisis dengan menghitung presentase skala Likert yang memperoleh presentase rata-rata pengukuran Likert sebesar $89,4 \%$. Jika dibandingkan dengan kriteria kelayakan, maka skor tersebut termasuk dalam kriteria sangat kuat atau sangat layak digunakan dalam pembelajaran.

Dari hasil pelaksanaan pre-test dan posttest kelas XI MIPA 1 (Kelas Kontrol) dan XI MIPA 2 (Kelas Eksperimen) SMA NEGERI 1 Tompaso tahun ajaran 2017/2018 pada uji coba lapangan akan disajikan dalam bentuk table nilai pre-test dan post-test kelas XI MIPA 1 dan kelas XI MIPA 2

Tabel 1 Nilai Pre-test Kelas Eksperimen dan Kelas Kontrol

\begin{tabular}{ccccc}
\hline Kelas & $\begin{array}{c}\text { Jumlah } \\
\text { Siswa }\end{array}$ & $\begin{array}{c}\text { Nilai } \\
\text { Minimal }\end{array}$ & $\begin{array}{c}\text { Nilai } \\
\text { Maksimal }\end{array}$ & $\begin{array}{c}\text { Rata- } \\
\text { rata }\end{array}$ \\
\hline Eksperimen & 25 & 55 & 80 & 65,28 \\
Kontrol & 25 & 50 & 61 & 56,48 \\
\hline
\end{tabular}

Berdasarkan data pada tabel kelas eksperimen ditunjukkan nilai pre-test dengan nilai terendahnya adalah 55 , nilai tertingginya adalah 80. Tidak berbedah jauh dengan nilai pre-test kelas kontrol nilai terendahnya adalah 50, nilai tertingginya adalah 61. Sedangkan rata-rata nilai pre-test kelas eksperimen adalah 65,28 dan rata-rata nilai pre-test kelas kontrol adalah 56,48 .

Tabel 2 Nilai Post-test Kelas Eksperimen dan Kelas Kontrol

\begin{tabular}{ccccc}
\hline Kelas & $\begin{array}{c}\text { Jumlah } \\
\text { Siswa }\end{array}$ & $\begin{array}{c}\text { Nilai } \\
\text { Minimal }\end{array}$ & $\begin{array}{c}\text { Nilai } \\
\text { Maksimal }\end{array}$ & $\begin{array}{c}\text { Rata- } \\
\text { rata }\end{array}$ \\
\hline Eksperimen & 25 & 68 & 90 & 78,64 \\
Kontrol & 25 & 51 & 80 & 66,64 \\
\hline
\end{tabular}

Dari data yang ada pada tabel di atas, baik kelas eksperimen maupun kelas kontrol mengalami peningkatan pada post-test. Nilai post-test kelas eksperimen yang terendah adalah 68, nilai tertingginya adalah 90 sedangkan nilai post-test kelas kontrol yang terendah adalah 51 dan nilai tertingginya adalah 80. Dengan rata-rata nilai post-test kelas eksperimen yaitu 78,64 dan nilai ratarata post-test kelas kontrol adalah 66,64.
Data nilai post-test adalah merupakan kemampuan siswa setelah diberikan perlakuan. Perlakuan yang dimaksud adalah siswa kelas eksperimen telah diajarkan dengan menggunakan perangkat pembelajaran fisika yang telah dikembangkan, sedangkan pada kelas kontrol diajar dengan menggunakan perangkat pembelajaran yang ada di sekolah. Kemudian diberi post-test untuk kedua kelas tersebut untuk mengetahui kemampuan siswa dalam memahami materi dengan menggunakan bahan ajar yang berbeda.

Selanjutnya data post-test kelas eksperimen dan post-test kelas kontrol dianalisis melalui uji $\mathrm{t}$ dua sampel (Paired Sample T Test) menggunakan software SPSS 22, dengan tingkat kemaknaan 0,05. Teknik analisis ini dilakukan untuk mengetahui ada tidaknya pengaruh perlakuan yang dikenakan pada kelompok objek penelitian.

\section{Langkah 1 Uji data statistik deskriptif}

Uji data ini dilakukan untuk mengetahui nilai minimum dan maksimum, rata-rata dan simpangan baku pada kelas eksperimen dan kelas kontrol dengan menggunakan software SPSS 2.

Tabel 3 Uji Descriptive statistics

\begin{tabular}{|c|c|c|c|c|c|}
\hline & $N$ & Min & $\operatorname{Max}$ & Mean & $\begin{array}{c}\text { Std. } \\
\text { Deviation }\end{array}$ \\
\hline $\begin{array}{c}\text { Pre-test } \\
\text { Kelas }\end{array}$ & 25 & 55 & 80 & 65,28 & 7,150 \\
\hline \multicolumn{6}{|c|}{ Eksperimen } \\
\hline $\begin{array}{c}\text { Post-test } \\
\text { Kelas }\end{array}$ & 25 & 68 & 90 & 78,64 & 6,607 \\
\hline \multicolumn{6}{|c|}{ Eksperimen } \\
\hline $\begin{array}{c}\text { Pre-test } \\
\text { Kelas }\end{array}$ & 25 & 50 & 61 & 56,48 & 3,016 \\
\hline $\begin{array}{c}\text { Kontrol } \\
\text { Post-test } \\
\text { Kelas }\end{array}$ & 25 & 51 & 80 & 66,64 & 6,683 \\
\hline $\begin{array}{l}\text { Kontrol } \\
\text { Valid N } \\
\text { (listwise) }\end{array}$ & 25 & & & & \\
\hline
\end{tabular}

Dari data hasil analisis uji data statistik deskriptif menggunakan software SPSS 22 menunjukkan jumlah nilai minimum kelas eksperimen pada pre-test adalah 55 dan posttest adalah 68, jumlah nilai maksimumnya pada pre-test adalah 68 dan post-test 90 dengan rata-rata nilai pre-test 65,28 dan posttest 78,64. Sedangkan jumlah nilai rata-rata pre-test kelas kontrol 56,48 dan rata-rata nilai post-test kelas kontrol 66,64. Simpangan baku nilai pre-test kelas eksperimen adalah 7,130 dan nilai post-testnya 7,239 dan simpangan baku nilai pre-test kelas kontrol 9,241 dan nilai post-test nya 6,97 .

Langkah 2 Uji Normalitas 
Sebelum dilakukan uji sampel $\mathrm{t}$ test terlebih dahulu dilakukan uji normalitas Kolmogrov-Smirnov untuk mengetahui apakah data nilai berdistribusi normal atau tidak. Dasar pengambilan keputusan dalam uji normalitas Kolmogrov-Smirnov, yaitu:

1. Jika nilai signifikansi ( $\mathrm{sig})>0,05$ maka data berdistribusi normal

2. Jika nilai signifikansi (sig) $<0,05$ maka data tidak berdistribusi normal

Tabel 4 Uji Normalitas Kolmogrov-Smirnov

\begin{tabular}{|c|c|c|c|c|}
\hline & Kelas & Statistic & $D f$ & Sig. \\
\hline \multirow{4}{*}{$\begin{array}{c}\text { Hasil } \\
\text { Belajar } \\
\text { Siswa }\end{array}$} & $\begin{array}{c}\text { Pre-test } \\
\text { Kelas } \\
\text { Eksperimen }\end{array}$ & 0,135 & 25 & 0,200 \\
\hline & $\begin{array}{c}\text { Post-test } \\
\text { Kelas } \\
\text { Eksperimen }\end{array}$ & 0,142 & 25 & 0,200 \\
\hline & $\begin{array}{c}\text { Pre-test } \\
\text { Kelas } \\
\text { Kontrol }\end{array}$ & 0,156 & 25 & 0,120 \\
\hline & $\begin{array}{c}\text { Post-test } \\
\text { Kelas } \\
\text { Kontrol }\end{array}$ & 0,139 & 25 & 0,200 \\
\hline
\end{tabular}

Berdasarkan pada tabel uji normalitas Kolmogrov-Smirnov (lampiran 5) menunjukkan bahwa nilai signifikansi (sig) pre-test kelas Eksperimen adalah 0,200 lebih dari 0,05 maka data berdistribusi normal, nilai signifikansi (sig) post-test kelas eksperimen 0,200 maka data berdistribusi normal, nilai signifikansi (sig) pre-test kelas kontrol adalah 0,120 lebih dari 0,05 maka data berdistribusi normal, nilai signifikansi (sig) post-test kelas kontrol 0,200 maka data berdistribusi normal.

\section{Langkah 3 Menentukan Kriteria Uji T}

Uji Paired Sample $T$ Test merupakan bagian dari statistic parametric, oleh karena itu sebelum melakukan uji Paired Sample Test data harus di uji normalitas terlebih dahulu dan berdasarkan tabel uji normalitas KolmogrovSmirnov, data penelitian berdistribusi normal, maka bias dilakukan Uji Paired Sample T Test.

Kriteria pengujian hipotesis pada hasil belajar dengan melakukan Uji Paired Sample $T$ Test, yaitu:

Tingkat kepercayaan 95\% maka tingkat kekeliruan adalah 5\% atau 0,05

$$
\mathrm{H}_{0}=\mu_{1} \geq \mu_{2}
$$

Jika nilai signifikan (sig) $>0,05 / t_{\text {hitung }}<$ $\mathrm{t}_{\text {tabel }}$ maka $\mathrm{H}_{0}$ diterima dan $\mathrm{H}_{1}$ Ditolak, artinya tidak ada perubahan hasil belajar siswa.

$$
\mathrm{H}_{1}=\mu_{1}<\mu_{2}
$$

Jika nilai signifikan (sig) $<0,05 / t_{\text {hitung }}>$ $\mathrm{t}_{\text {tabel }}$ maka $\mathrm{H}_{0}$ ditolak dan $\mathrm{H}_{1}$ diterima, artinya ada perubahan hasil belajar siswa.

\section{Langkah 4 Uji Paired Sample T Test}

Uji Paired Sample T Test merupakan bagian dari statistic parametric, oleh karena itu sebelum melakukan uji Paired Sample Test data harus di uji normalitas terlebih dahulu dan berdasarkan tabel uji normalitas KolmogrovSmirnov, data penelitian berdistribusi normal, maka bisa dilakukan Uji Paired Sample T Test.

Tabel 5 Uji Paired Sample T Test

\begin{tabular}{lccc} 
& $T$ & $d f$ & $\begin{array}{l}\text { Sig (2- } \\
\text { tailed) }\end{array}$ \\
\hline $\begin{array}{l}\text { Kelas } \\
\text { Eksperimen }\end{array}$ & 15,295 & 24 & 0,000 \\
$\begin{array}{l}\text { Kelas } \\
\text { Kontrol }\end{array}$ & 9,736 & 24 & 0,000 \\
\hline \multicolumn{2}{l}{ Berdasarkan tabel } & Uji & Paired Sample T
\end{tabular}

Test (Lampiran 5) diperoleh nilai signifikansi(sig) pre-test dan post-test kelas eksperimen dan kelas kontrol yaitu 0,000 < 0,05 . Dengan derajat kebebasan (df) kelas eksperimen yaitu 24 dan kelas kontrol yaitu 24.

Pada tabel $\mathrm{t}_{0,05}: 24=1,71088$

Berdasarkan $t_{\text {hitung }}$ pada tabel Uji Paired Sample $T$ Test diperoleh nilai $\mathrm{t}$ kelas eksperimen

\section{$\mathrm{t}_{\text {hitung }}=15,295$}

Berdasarkan kriteria pengujian hipotesis untuk melihat ada tidaknya perubahan dalam hasil belajar siswa SMA N 1 Tompaso dengan perangkat pembelajaran fisika berbasis masalah menggunakan alat peraga fluida dinamis yang dikembangkan, $t_{\text {hitung }}>t_{\text {tabel }}$ maka $\mathrm{H}_{0}$ ditolak dan $\mathrm{H}_{1}$ diterima yang artinya ada perubahan signifikan dalam hasil belajar siswa menggunakan perangkat pembelajaran yang dikembangkan oleh peneliti.

\section{Pembahasan}

Dengan masalah yang diidentifikasikan pada bagian sebelumnya, dimana pembelajaran Fisika di SMA Negeri 1 Tompaso cenderung didominasi oleh guru tanpa mengolah potensi yang ada pada peserta didik, akibatnya belum mengajak siswa berpikir kritis terhadap konsep-konsep dan prinsip-prinsip yang telah dipelajarinya serta aspek keterampilan dan sikap juga terabaikan. Maka peneliti mengembangkan suatu produk 
perangkat pembelajaran Fisika dengan model pembelajaran berbasis masalah "ProblemBased Learning" (PBL) menggunakan alat eksperimen dan demonstrasi dalam materi Fluida Dinamis yang bertujuan untuk meningkatkan nilai hasil belajar Fisika siswa di SMA Negeri 1 Tompaso.

Setelah memenuhi prosedur pengembangan, maka produk pengembangan perangkat pembelajaran fisika yang dihasilkan adalah silabus, rencana pelaksanaan pembelajaran (RPP) dengan menggunakan model pembelajaran berbasis masalah "Problem Based Learning" (PBL), Buku Siswa, lembar kerja siswa (LKS) serta alat eksperimen dan demonstrasi yang dikemas secara menarik dan sesederhana mungkin agar bisa memotivasi siswa untuk berpikir kritis dalam menerapkan dan mengelolah setiap unsur-unsur konsep yang dipelajari.

Penyajian materi dalam pembelajaran ini pun tidak hanya berpusat pada teori pembelajaran saja tetapi sudah langsung dipraktikkan. Siswa dibagi menjadi kelompokkelompok kecil untuk mempraktikkan alat eksperimen dan demonstrasi sederhana berupa botol bocor "Teorema Toricelli", Pipa Venturi tanpa Manometer, animasi menggunakan simulasi PhET serta video animasi penerapan Hukum Bernoulli pada sayap pesawat. Alat peraga yang dibuat dengan menarik membuat siswa bersemangat untuk belajar dan termotivasi untuk mencari tahu sifat-sifat fisis pada alat eksperimen dan demonstrasi yang disajikan. Adapun buku siswa dengan materi Fluida Dinamis yang dibuat dengan menarik dan bahasa yang mudah dimengerti.

Dengan menggunakan model pembelajaran Problem Based Learning (PBL) pada kelas eksperimen (XI MIPA 2), siswa disajikan sebuah masalah yang berkaitan dengan materi yang dipelajari dan harus dipecahkan siswa dengan memotivasi siswa untuk meningkatkan rasa ingin tahu, kemampuan analisis, juga inisiatif dan berperan aktif dalam pembelajaran. Siswa dibagi kedalam kelompok kecil untuk berdiskusi kemudian membahas informasi yang faktual dan juga informasi yang dimiliki setiap siswa. Setelah itu siswa mengembangkan hasil karya melalui laporan praktikum yang akan dipresentasikan bersama kelompok.

Banyak kelebihan dengan menggunakan
Problem Based Learning (PBL) dalam pembelajaran, seperti pernyataan Sanjaya (2007), yaitu: (1) Menantang kemampuan siswa serta memberikan kepuasan untuk menemukan pengetahuan baru bagi siswa; (2) Meningkatkan motivasi dan aktivitas pembelajaran siswa; (3) Membantu siswa dalam mentransfer pengetahuan siswa dalam memahami masalah dunia nyata; (4) Membantu siswa untuk mengembangkan pengetahuan barunya dan bertanggung jawab dalam pembelajaran yang mereka lakukan; (5) Mengembangkan kemampuan siswa untuk berpikir kritis dan mengembangkan kemampuan mereka untuk menyesuaikan dengan pengetahuan baru; (6) Memberikan kesempatan bagi siswa untuk mengaplikasikan pengetahuan yang mereka miliki dalam dunia nyata; (7) Mengambangkan minat siuswa untuk secara terus-menerus belajar sekalipun belajar pada pendidikan formal telah berakhir; dan (8) Memudahkan siswa dalam menguasai konsep-konsep yang dipelajari guna memecahkan masalah dunia nyata.

Pada bagian sebelumnya seperti yang telah penulis jabarkan, bahwa teori Fisika tidak hanya cukup dibaca, sebab teori Fisika tidak sekedar hafalan saja akan tetapi harus dibaca dan dipahami dan dipraktikkan sehingga peserta didik mampu menjelaskan permasalahan yang ada. Hal ini sangat berhubungan dengan penerapan model pembelajaran Problem Based Learning (PBL) pada materi Fluida Dinamis yang membahas tentang Asas Kontinuitas, Asas Bernoulli, serta penerapan Prinsip Bernoulli pada Teorema Toricelli dan Gaya Angkat Pesawat. Karena jika fenomena fisis yang sedang dibahas telah pernah dialami oleh siswa maka siswa akan dapat merekontruksinya kembali mejadi pemahaman yang lebih baik. Maka hasil belajar siswa XI MIPA 2 SMA Negeri 1 Tompaso menjadi lebih baik.

Berdasarkan validasi ahli materi pengamatan yang dilakukan mencapai $86,7 \%$, pengamatan yang dilakukan ahli media pembelajaran mencapai $96,7 \%$ dan pengamatan yang dilakukan oleh ahli perangkat pembelajaran mencapai $98,9 \%$. Maka Pengembangan Perangkat Pembelajaran Fisika Berbasis Masalah Menggunakan Alat Peraga Fluida Dinamis sudah valid atau layak digunakan karena sudah sesuai dengan kurikulum 2013 PP. No. 53 Tahun 2015. 
Sebelum melakukan kegiatan pembelajaran dengan perangkat pembelajaran yang dikembangkan terlebih dahulu dilakukan tes awal untuk mengetahui kemampuan awal siswa dan setelah kegiatan pembelajaran dilakukan tes untuk mengetahui apakah ada peningkatan terhadap hasil belajar siswa setelah menggunakan perangkat pembelajaran yang dikembangkan. Berdasarkan nilai hasil dari pre-test dan post-test kelas eksperimen mengalami peningkatan rata-rata nilai hasil belajar yang lebih baik dari peningkatan ratarata nilai pre-test dan post-test kelas kontrol, hal ini membuktikan bahwa terdapat perbedaan yang signifikan pada tingkat hasil belajar antara siswa kelas XI MIPA 2 (kelas eksperimen) yang menggunakan Pengembangan Perangkat Pembelajaran Fisika Berbasis Masalah Menggunakan Alat Peraga Fluida Dinamis dengan kelas XI MIPA 1 (kelas kontrol) yang tidak menggunakan Pengembangan Perangkat Pembelajaran Fisika Berbasis Masalah Menggunakan Alat Peraga Fluida Dinamis.

Menurut Tumangkeng, J. (2021) ada beberapa penelitian tentang pengembangan perangkat pembelajaran Fisika dan penelitian tentang alat Peraga Fluida Dinamis seperti Punarbawa, Dewa(2018) dengan penelitian alat peraga Pipa Venturi (Venturimeter dengan manometer) dan Komalig, Gabriel(2018) dalam skripsi"Pengembangan Perangkat Pembelajaran Fisika Dengan Pemanfaatan Lingkungan Berbasis Eksperimen dan Teknik Assesmen Proyek" yang menuntun siswa belajar bereksperimen dalam pelaksanaan tugas proyek yang berinteraksi dengan lingkungan sekitar. Dalam penelitian ini, peneliti mengembangkan perangkat dengan menggunakan metode penelitian dan pengembangan "research and development" (R \& D) dengan mengikuti tahap-tahap penelitian pengembangan Borg dan Gall dan spesifikasi produk perangkat pembelajaran seperti yang telah dijelaskan pada bagian sebelumnya serta menggunakan model pembelajaran berbasis masalah "Problem Based Learning" yang bertujuan seperti menurut Trianto (2010: 94-95) menyatakan bahwa "tujuan $P B L$ yaitu membantu siswa mengembangkan keterampilan berpikir dan keterampilan mengatasi masalah, belajar peranan orang dewasa yang autentik dan menjadi pembelajar yang mandiri”.
Dapat dikatakan bahwa Pengembangan Perangkat Pembelajaran Fisika Berbasis Masalah Menggunakan Alat Peraga Fluida Dinamis ini secara efektif mampu meningkatkan hasil belajar siswa kelas XI MIPA 2 karena perangkat pembelajaran didesain berdasarkan karakterisktik pengguna sehingga bisa digunakan dalam kegiatan pembelajaran oleh siswa. Dari paparan analisis data menggunakan software SPSS 22, penyusunan perangkat pembelajaran dan pelaksana penelitian menggunakan perangkat pembelajarn yang dikembangkan, dapat diketahui alasan adanya peningkatan hasil belajar siswa sebelum dan sesudah menggunakan Perangkat Pembelajaran Fisika Berbasis Masalah Menggunakan Alat Peraga Fluida Dinamis yang dikembangkan. Hal tersebut menjadi alasan Perangkat Pembelajaran Fisika Berbasis Masalah Menggunakan Alat Peraga Fluida Dinamis dapat meningkatkan hasil belajar siswa kelas XI MIPA 2 SMA Negeri 1 Tompaso tahun ajaran 2017/2018.

\section{KESIMPULAN}

Pengembangan Perangkat Pembelajaran Fisika Berbasis Masalah Menggunakan Alat Peraga Fluida Dinamis menghasilkan produk berupa silabus, rencana pelaksaaan pembelajaran (RPP) menggunakan model pembelajaran berbasis masalah "Problem Based Learning" (PBL), alat-alat eksperimen dan demonstrasi seperti (botol bocor "Teorema Toricelli", pipa venturi tanpa manometer, simulasi animasi PhET dan video/gambar pesawat terbang), lembar kerja siswa (LKS-01 menuntun siswa dalam menyelidiki debit fluida melalui simulasi PhET "Fluid Presassure and Flow, LKS-02 menuntun siswa dalam bereksperimen botol bocor untuk menyelidiki pengaruh Hukum Bernoulli terhadap Teorema Toricelli, LKS-03 menuntun siswa dalam bereksperimen ventirumeter tanpa manometer untuk menjelaskan penerapan Hukum Bernoulli dan LKS-04 menuntun siswa dalam menyelidiki pengaruh Hukum Bernoulli terhadap gaya angkat pesawat), buku siswa dengan materi Fluida Dinamis yang dibuat semenarik mungkin agar mudah dipahami. Produk perangkat pembelajaran yang dikembangkan juga telah memenuhi komponen sebagai perangkat pembelajaran yang baik digunakan 
karena sesuai dengan kurikulum 2013 sesuai dengan karakteristik siswa dan menggunakan bahasa yang mudah untuk dimengerti. Berdasarkan penilaian para ahli materi, ahli media, dan ahli perangkat pembelajaran yang menyatakan Produk Pengembangan Perangkat Pembelajaran Fisika Berbasis Masalah Menggunakan Alat Peraga Fluida Dinamis termasuk dalam kriteria sangat valid atau layak digunakan dalam kegiatan pembelajaran.

Perolehan hasil belajar berdasarkan uji lapangan pada kelas XI MIPA 2 SMA Negeri 1 Tompaso tahun ajaran 2017/2018 yang diukur dengan tes mencapaian hasil belajar. Berdasarkan analisis data yang dilakukan menggunakan software SPSS 22, menunjukkan bahwa $t_{\text {hitung }}>\mathrm{t}_{\text {tabel }}$ yaitu $\mathrm{t}_{\text {hitung }}=15,295>\mathrm{t}_{\text {tabel }}$ $=1,71088$. Dengan peningkatan rata-rata nilai hasil belajar siswa yaitu 13,30 maka dapat disimpulkan bahwa adanya perbedaan yang signifikan terhadap peningkatan hasil belajar materi fluida dinamis pada kelas eksperimen, dengan menggunakan Perangkat Pembelajaran Fisika Berbasis Masalah Menggunakan Alat Peraga Fluida Dinamis.

Adapun jumlah siswa yang mengikuti pembelajaran menggunakan perangkat pembelajaran ini berjumlah 25 orang. Berdasarkan data yang diambil dari tabel tanggapan siswa kelas XI MIPA 2 SMA Negeri 1 Tompaso terhadap Perangkat Pembelajaran Fisika Berbasis Masalah Menggunakan Alat Peraga Fluida Dinamis yang dianalisis dengan perhitungan prosentase skala Likert yang memperoleh prosentase rata-rata pengukuran Likert sebesar $89,4 \%$ yang jika dibandingkan dengan kriteria kelayakan, maka skor tersebut termasuk dalam kriteria sangat kuat atau sangat layak digunakan dalam pembelajaran. Hal ini karena materi yang ada didalam perangkat pembelajaran dibuat dengan menarik dan sesederhana mungkin serta memotivasi siswa untuk belajar dan memecahkan masalah.

\section{REFERENSI}

Arikunto, S. 2015. Dasar-dasar Ecaluasi Pendidikan Edisi kedua Cetakan Keempat. Jakrta: PT. Bumi Aksara

Barret, T., \& Moore, S. (2011). New Approaches to Problem-Based Learning: Revitalising your Practice in Higher Education. New York: Routledge.

Basar, Khairul. 2004. Mengkaji Kembali
Pengajaran Fisika di Sekolah Menengah (SMP dan SMA) di Indonesia. Inovasi Online - Vol.2/XVI/November 2004. http://io.ppi-

jepang.org./article.php?id=45, diakses tanggal 18 September 2017.

De Graaff, E., \& Kolmos, A. (2003). Characteristics of problem-based learning. International Journal of Engineering Education, 19(5), 657-662. https://doi.org/0949-149X/91. Diakses tanggal 20 Mei 2021

Diani, Rahma. (2013). Pengembangan Perangkat Pembelajaran Fisika Berbasis Pendidikan Karakter dengan Model Problem Based Instruction dan indikator dampaknya terhadap kompetensi siswa, M. Pd. Tesis. Pendidikan Fisika Program Pascasarjana Universitas Negeri Padang

Downing, K. 2010. Problem Based Learning and the development Metacognition. Asian Journal on Education and Learning, 1(2), 75-96.

Erda, V., Razak, A., \& Sumarmin, R. (2018). The Effect of Model Problem Based Learning of Learning Outcomes Student Course on Animal Ecology Based on Learning Styles. International Journal of Progressive Sciences and Technologies, 538(2), 533-538.

Gall, J.P, dan Borg, W.R. 2003. Educational research: An introduction. Edisi7.Boston, M.A Pearson Education

Gunada,I.W., Sahidu, K., \& Sutrio. 2015. Pengembangan Perangkat Pembelajaran Fisika Berbasis Masalah unttuk Meningkatkan Hasil Belajar dan Sikap Ilmiah Mahasiswa. Jurnal Pendidikan Fisika dan Teknologi, 1(1), 38-46.

Khamzawi. 2015. Pengembangan Multimedia Interaktif Berbasis Model Pembelajaran Problem Based Learning Pada Mata Pelajaran Fissika Pokok Bahasan Fluida Dinamis Untuk SMA Kelas XI. Jurnal Inovasi dan Pembelajaran Fisika, 2(1), 100-108

Murray-harvey, R., Pourshafie, T., \& Reyes, W. S. (2013). What teacher education students learn about collaboration from problem-based learning. Journal of Problem Based Learning in Higher Education, 1(1), 114-134.

Pinto, R., \& Boudamoussi, S.E. (2009). "Scientific processes in PISA test 
observed for science teacher". International Jurnal of Science Education. Vol. 31, No. 16, November 2009, pp. 2131-2159.

Pitriah, P., Sutrio, S., \& Taufik, M. (2018). Pengaruh Model Pembelajaran Berbasis Masalah Berbantuan Alat Peraga Tiga Dimensi terhadap Hasil Belajar Fisika Peserta Didik Tahun Pelajaran 2017/2018. Jurnal Pendidikan Fisika dan Teknologi, 4(2), 283-290.

Susdarwati, S., Sarwanto, S., \& Cari, C. (2016). Pengembangan Perangkat Pembelajaran Fisika Berbasis Problem Based Learning ( $\mathrm{Pbl}$ ) Pada Materi Hukum Newton Dan Penerapannya Kelas X Sman 2 Mejayan. Inkuiri, 5(3), 1-11.

Zuhdan, K. P, dkk. 2011, Pengembangan Perangkat Pembelajaran Sains Terpadu Untuk Meningkatkan Kognitif, Keterampilan Proses, Kreativitas, Serta Menerapkan Konsep Ilmiah Peserta Didik SMP. Yogyakarta; Pascasarjana Universitas Yogyakarta. 